\title{
PHONOLOGICAL REMARKS ON SPANISH LOANWORDS IN ENGLISH
}

\section{CONSIDERACIONES FONOLÓGICAS SOBRE LOS PRÉSTAMOS DEL ESPAÑOL EN INGLÉS}

\author{
ESTRELLA RAMÍREZ QUESADA \\ Universidad de Córdoba \\ 162raque@uco.es
}

\begin{abstract}
This paper focuses on loanword phonology in the context of Spanish words that have become part of the English lexicon in the $20^{\text {th }}$ century. The background section shows that attention has been paid to Spanish words used in English from a lexical point of view, but scarcely regarding phonology. Furthermore, the few existing studies of loanword phonology do not deal in depth with Spanish and English as an example of crosslinguistic contact. Therefore, this paper aims at contributing to the explanation of the phonological adaptations occurring in Spanish words when integrated into English, and therefore the conditions of English phonology that operate in the process of perception and production of Spanish loanwords. In doing so, two areas of interest are analysed: vowel phonemes and consonant phonemes, mainly in relation to their distinctive features and the distribution of units and also considering related phenomena such as phonetic and orthographical factors.
\end{abstract}

Keywords: phonology, loanwords, English, Spanish, phonemes.

\section{Resumen}

Este artículo se centra en la fonología de los préstamos en el caso de las palabras del español que han pasado a formar parte del léxico del inglés en el siglo XX. El 
apartado dedicado a los antecedentes muestra que principalmente se ha prestado atención a los préstamos del español en inglés desde un punto de vista léxico, pero en pocas ocasiones en relación con la fonología. Por otra parte, los estudios de la fonología de los préstamos no tratan en profundidad la relación entre el inglés y el español como ejemplo de contacto interlingüístico. Así pues, con este artículo tratan de explicarse las adaptaciones fonológicas que se producen en las palabras del español que se integran en la lengua inglesa y, en consecuencia, los condicionantes de la fonología inglesa que operan en el proceso de percepción y producción de los préstamos hispánicos. En esta línea, se analizan dos áreas de interés: los fonemas vocálicos y los fonemas consonánticos, con arreglo a los rasgos distintivos y la distribución de las unidades y teniendo en consideración otros fenómenos como los factores fonéticos y ortográficos.

Palabras clave: fonología, préstamos, inglés, español, fonemas.

\section{Introduction}

The influence of the Spanish language in English is a well-known phenomenon that has attracted a significant amount of research works and projects, such as Algeo (1996), Cannon (1996) or Schultz (2018), in the area of crosslinguistic contact. The aim of this paper is to focus on the phonological adaptations of Spanish words existing in English. Several studies, such as those mentioned above, have been done from the lexical point of view, i.e. the number of words incorporated into English, periods of deeper cultural contact, and areas of vocabulary more permeable to Spanish words, among other topics of interest. However, my purpose is different as I intend to explain phonologically the assimilation of Spanish words in terms of the distinctive features of English and Spanish in confrontation. In other words, this analysis focuses on segmental units.

\section{Background}

This study deals with loanword adoption, a process within the larger concept of borrowing in which lexical units from one language are adopted by another by means of the native speakers of the recipient language. Subject to nativization, these words are introduced in the target lexicon, and thus become 'undistinguished' from the native words and fully integrated in the vocabulary (Winford 2010). In this section, the studies of Spanish loanwords in English will be reviewed, as well as the role of oral and written forms in the transferring process (in general linguistics), and the concepts of phonology which are key to the analysis. 


\subsection{The Presence of Spanish Words in English}

The topic of the Spanish influence in the English language has been approached in several works, mainly from the point of view of lexical units that have entered the English lexicon due to cultural contact. Since the classical history of foreign words in English by Serjeantson (1936), which includes a chapter about the Spanish element in English, many lexical approaches to this area have emerged. Algeo (1996) focuses on loans by 1900 and points out that Spanish is also an intermediate language by which other foreign words - especially from Amerindian languages and European languages - become part of the English vocabulary. Cannon (1996) analyses borrowings in the $20^{\text {th }}$ century and lists new Spanish words that became common in English considering the main contemporary lexical repertories; however, phonology is barely mentioned, and in the few cases where it is, this is mainly in relation to suffixes as in the transformation of -ista in -ist.

Besides, Arnold (2015) deals with American English. The most recent contribution to Spanish loanwords in English is Schultz (2018), focusing on cultural, contextual, and linguistic information about the lexical units that have been adopted since the $19^{\text {th }}$ century. Her book is the most extensive compilation on the topic. However, the limited presence of phonology in previous studies leads us to propose a more in-depth analysis of this area, being of great importance in the phenomenon of borrowing.

\subsection{Phonology in Loanwords}

Many aspects are involved in loanwords. Vendelin and Peperkamp mention that "orthography is rarely taken into account as a possible factor in loanword adaptations, and when it is, its influence is usually described as marginal at most" (2006: 997). These authors have studied the interrelation of orthography and oral input in loanwords, concluding after an experiment that "in the oral condition, the adaptations were more varied" (2006: 1004), and confirming the sensitivity of adaptations to the presence of a written representation. I have argued that although orthography is important for English loanwords in Spanish, it is not the only factor, as phonology plays a key role too (Ramírez Quesada 2020). It is my aim to investigate what happens in the reverse direction (Spanish words in English), especially with respect to phonology, an area which remains unexplored.

Despite the interest in the phonology of loans in general linguistics, the SpanishEnglish transfer has not been addressed. In general linguistics, Sayahi (2005) points out that the phonology of loans is called on to shed light on universal phonological patterns. Also, according to Calabrese and Wetzels,

loanword nativization provides a direct window for studying how acoustic cues are categorized in terms of the distinctive features relevant to the $\mathrm{Ll}$ phonological 


\section{Estrella Ramírez Quesada}

system as well as for studying the true synchronic phonology of Ll by observing its phonological processes in action. (2009: 1)

The importance of this area is later supported: "In the last couple of decades, loanword phonology has gained prominence as a productive research area of theoretical significance" (Kang 2010: 2295).

There are two main scenarios in loan reception: a borrowing is introduced by a bilingual speaker (already knowing the word) to fill a gap in the recipient language, or the borrowing is introduced by people lacking accurate knowledge of the donor language, a scenario where perception plays a major role. ${ }^{1}$ According to Calabrese and Wetzels (2009), these processes have led to two main approaches to loanword phonology (see Calabrese 2009 for a review of the most important currents). In their study about the theory of phonology in loanwords, Peperkamp and Dupoux (2003) claim a more relevant role for phonetics. In their words, "loanword adaptations generally receive a phonological analysis, according to which they constitute phonologically minimal repairs that render illegal foreign forms in conformity with the native phonology. However, more than one such phonologically minimal repair is often available" (2003: 368). This is where phonetics comes in. The relevance of phonetics was later analysed by Peperkamp (2006). As regards the phonology/phonetics interface, studies such as Rose and Demuth (2006) can be highlighted, in which the authors review the controversy before carrying out their own analysis of English and Afrikaans loanwords in Sesotho. Phonology plays a major role for several authors, either as the main factor or in combination with perception. The intermediate position - both grammar and perception are relevant - has recently been defended by Yip (2006). Besides, Boersma and Hamann (2009) mention that structural constraints play a role in perception and consider that perception is itself phonological. Although discussion on theoretical phonology is outside the scope of this paper, the conciliating view of these authors, which I share, is that "loanword adaptation is fully explained by the behaviour of listeners in their native language” (2009: 53).

Interest has been given to segmental phonology, and the suprasegmental features of loanwords have been treated on some occasions. Kubozono (2006) draws attention to stress patterns within the controversy between the importance of phonetics and phonology in loanwords and the structure of the languages involved. Kang (2010) focuses on suprasegmental features and reviews the studies dealing with pitch, tone and accent, pointing out that some tone and pitch accent languages are less disposed to maintain suprasegmental elements of the foreign word because of the complexity of their own system, and this applies to stress languages too. There are also works devoted to loanwords in specific languages. 
In particular, in relation to Spanish, Sayahi (2005) focuses on the phonology of Spanish loanwords in Northern Moroccan Arabic, taking several previous studies at the lexical level as a starting point. Strategies for preservation, epenthesis, deletion, and other phenomena are examined considering the differences between the two phonological systems, both at the segmental and the suprasegmental levels. Adell deals with the phonology of Spanish loans in Kaqchikel, aiming at examining "observable assimilatory processes by which Spanish words may have entered the Kaqchikel lexicon" (2013: 1). These papers show that Spanish loanwords are a topic of potential study and need further attention in relation to other languages in which they are integrated.

\subsection{Phonological Concepts Considered}

Trubetzkoy's classical book on phonology (1939) does not fail to address languages in contact, stating that sounds of a foreign language are interpreted in an inaccurate phonological manner due to the fact that listeners transfer the phonic values of their own language to those linguistic units. In his words,

whenever we hear a sound in a foreign language which does not occur in our mother tongue, we tend to interpret it as a sound sequence and to regard it as the realization of a combination of phonemes of our mother tongue. (1969: 63)

This idea has been widely accepted and has led to the development of the concept of 'phonological deafness'. In the field of loanwords, this assumption implies that the less the knowledge of the foreign language, the more the native system participates in the phonological assimilation.

Peperkamp and Dupoux explain the process according to more recent studies from the point of view of psycholinguistics and say that

the native language distorts the way in which we produce, but also memorize, and even perceive foreign sounds. The phenomenon of phonological 'deafnesses', that is, the inability or extreme difficulty to discriminate certain nonnative contrasts, involves segmental and suprasegmental contrasts, as well as contrasts based on the presence versus absence of a segment. (2003: 367)

Similarly, Calabrese points out that

if a segment, or a syllabic combination of segments, is unfamiliar, foreign, i.e. absent from Ll, a speaker has no instructions for how to produce it, i.e. no representation of it with the right combinations of features, or segments in the case of syllable configurations. (2009: 83)

According to this author, it must be considered that some properties of unfamiliar sounds can be perceived, although some difficulties might arise when identifying what the differences consist of and, consequently, they are reassigned to familiar 


\section{Estrella Ramírez Quesada}

configurations. Training is therefore key to overcoming this situation and learning a new language. In other words, "deafening likewise does not imply an inability to hear or access the acoustic signal, but rather a lack of an ability to recognize acoustic configurations as phonological entities, and therefore to discriminate acoustic differences as instances of phonological contrasts" (Calabrese 2009: 94). However, this author states that the acoustic differences can be perceived when the adult speaker is made aware of them and pays attention.

It should be noted that phonology is central to understanding the phenomenon of linguistic transfer. The importance of contrastive phonology is widely recognized and employed in the process of learning a foreign language, and accordingly several handbooks comparing two phonological systems can be found. I believe that not only second language learning can benefit from applying a phonological perspective, but also the study of loanwords, in which these ideas can provide us with a more accurate knowledge of the results of the transfer of Spanish words into English. Moreover, as English and Spanish are languages sharing a relevant number of lexical units, studying the phonological conditions of the Spanish loanwords that can be found in English can give us valuable information about the phonological pattern of both languages, though phonology has been scarcely considered when approaching Spanish loanwords in English. Therefore, my contribution aims at filling this gap, at least partially.

\section{Methods}

Since not all the above-mentioned studies are based on corpora and they adopt different methodological options, in this comparison of the English and the Spanish systems I have selected a list of words which constitute a lexical basis for studying phonologically Spanish loanwords in English. The corpus of words used for the analysis is taken from Cannon (1996). His paper involves the identification from different lexicographical sources of the Spanish words assimilated in English during the $20^{\text {th }}$ century. There are other studies, among which Schultz (2018) can be highlighted. Schultz gathers 1,355 lexical items of Spanish etymology from 1801 to 2016, but these include English words formed out of Spanish etymology, not only loanwords. The reasons for choosing Cannon's list are the following: 1) his list of words - consisting of 153 items and 73 productive forms - is a large enough sample to be representative of loanwords; 2 ) the $20^{\text {th }}$ century constitutes a suitable period of time in order to observe the accommodation of words because there has been time enough for consolidation, avoiding vacillation of forms; and 3 ) given that this period is also relatively recent, phonological rules and ways of adaptation are indicative of current phonology. It must be said that phonetic 
details and variation among dialects are not the purpose of this study, which is mainly focused on phonology.

However, several restrictions have been placed on the initial corpus, finally consisting of 63 items for this analysis. ${ }^{2}$ Words with English morphemes have not been considered, as there are numerous words in the corpus in their Spanish form whose pronunciation is clear without being modified orthographically. Also, words not included in the Merriam-Webster Dictionary - a tool offering the phonological transcription of the words it contains - were omitted in order to ensure widely consolidated and reliable transcriptions of these loans. Words with new meanings - such as coyote or escudo- have also been avoided, because their pronunciation dates from before the $20^{\text {th }}$ century. Nevertheless, other words such as austral (referring to a coin) have been considered because the pronunciation of their new meaning differs from older ones. As for differences between British and American English, the Cambridge English Dictionary has also been consulted. Although local variations exist, it is my opinion that general assumptions about the behaviour of loanwords can be made. Also, pronunciation has been checked, when available, in the Forvo database, in order to contrast dictionary transcriptions with recent articulations of the words. The number of Spanish and English phonemes considered for this analysis corresponds to the widely-accepted ones; the inventory of Spanish phonemes is taken from the Real Academia Española's volume on phonology and phonetics (2011), ${ }^{3}$ whereas the English phonemes have been taken from Carr (2012), although other references are properly cited throughout the analysis. ${ }^{4}$ The transcriptions have been made according to the IPA system, although some minor phonetic properties — such as the differences between the Spanish / $/$ and the English / t/ - have not been represented because of their lack of phonological relevance.

\section{Vowels}

The difference in the number of vowel phonemes between Spanish and English is well known. According to several authors, including Alarcos Llorach (1965) and Quilis (1999), Spanish has only five units in its vowel system: /i/, /u/,/e/,/o/, $/ \mathrm{a} /{ }^{5}$ However, the number of English monophthongal phonemes is twelve units: $/ \Lambda /, / \mathrm{v} /, / \mathrm{u}: / \mathrm{s} /, / \mathrm{i}: /, / \varepsilon /$ (or $/ \mathrm{e} /$ ), $/ \mathrm{p} /$ (or $/ \mathrm{a} /$ ), / $/ \mathrm{s} /, / \mathfrak{x} /, / \mathrm{a}: /$ (or $/ \mathrm{a} /$ ), $/ 3: /$ (or $/ 3 /$ ), $/ \mathrm{o}^{\mathrm{6}} \mathrm{.}^{\mathrm{T}}$ There are also up to eight diphthongs, traditionally considered among the units of the phonological system (see Jensen 1993: 26-27, $\$ 2.3 .3$ ) because sometimes their occurrence relates to the occurrence or the non-

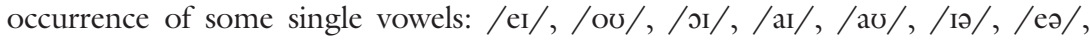
$/$ $/{ }^{7}$ In Spanish, diphthongs and triphthongs are usually treated as combinations 
of phonemes. Because of the small number of vowel phonemes, their area of dispersion is higher compared to that of English vowels. Concepts such as length or labialization, for instance, have no phonological value in standard Spanish, their vowel variants being freely articulated in most cases. In the following section, I analyse the phonological behaviour of the five Spanish vowels when introduced into English.

\subsection{Close Vowels}

In loanwords, the Spanish /i/, which is a close front vowel, is interpreted as /i:/ and $/ \mathrm{I} /$ in English, depending on the context. When stressed, Spanish vowels are perceptibly clearer (Navarro Tomás 1932: $\$ 42, \$ 44$ ), and this phonetic rule is phonologically transferred into English, which has two phonemes in the close to close-mid front area. Words such as burrito /bu'ri.to/ or ceviche /se'bi.ţe/ (or

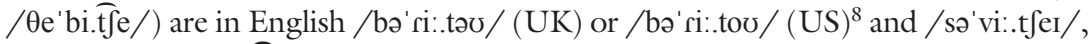

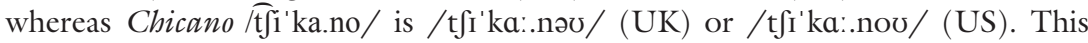
rule applies to other words such as Hispano, Latina, manoletina, margarita (in the sense of 'cocktail', not the geographical name), and turista, being /i:/ when the Spanish /i/ is stressed and /I/ when /i/ is not stressed in Spanish. Vacillating words are fewer, e.g., picadillo or sinsemilla, so the general rule is of importance in the matching process.

The other close vowel in Spanish, the back /u/, shows a similar interpretation (/u:/ when stressed, and / $/ /$ when not stressed), although in not such a clear manner as $/ \mathrm{i} /$. Again, in English we discover two phonemes in the near area of the Spanish /u/: /u:/ and / /. Words that follow the general rule are chulo, conjunto, cursillo, flauta, whereas there are other words with no clear choice. An example of both pronunciations for $/ \mathrm{u} /$ is churro, according to Merriam-Webster, but the Cambridge Dictionary gives only /'t $\int 0 . r ə o /(U K)$ and /'t $\int 0 . r o u /(U S)$ as transcriptions. A possible explanation lies in the darker and less clear perception of the phoneme. ${ }^{9}$ Adopting $/ \partial /$ is a sign that points in this direction: sometimes the undefined English central vowel known as the schwa, used in non-stressed syllables, is chosen for the Spanish unstressed /u/, the first vowel of burrito being a good example (although $[\mho]$ can be heard in a US sample taken from the Forvo database). Another phenomenon should be mentioned in relation to $/ \mathrm{u} /$ transferring. In some varieties of English, a / j/ element can be added when the Spanish / $\mathrm{u} /$ is preceded by a nasal $/ \mathrm{n} /$, due to the articulatory habits of the recipient language. This can result in the sequence /'nju:/ for the Spanish /'nu/, in nucleolonema and numero uno, for instance, although it is not the most frequent pronunciation. The structure is also responsible for interpreting the velar vowel sound in cuatro /'kua.tro/ as /w/: /'kwa.t.too/. 


\subsection{Mid Vowels}

The /e/ phoneme in Spanish words tends to adopt several forms in English. Covering the mid front area, its transformation mostly depends on the context. As expected, the non-stressed /e/ is usually expressed as $/ \partial /$, as in the first vowel in ceviche: /sa'vi..teeI/ (UK and US). However, the last vowel is converted into a diphthong - / eI - , because it is not common for English short vowels, except for $/ \partial /$, to occur in word-final position, where long vowels and diphthongs are preferred (see the checked/free distinction in Collins and Mees 2013: 100, and also Jensen 1993: 35). The same conversion rule applies to other phonemes, such as $/ \mathrm{a} /$ and $/ \mathrm{o} /$, since Spanish is a language where it is common to find words ending in $/ \mathrm{e} /, / \mathrm{a} /$ and $/ \mathrm{o} /$. In stressed or secondary-stressed syllables, /e / can be found as $/ \varepsilon /$ or $/ \mathrm{e} /$-depending on the front mid short phoneme of the English variety. Examples of this situation are perfecta/per'fek.ta/: /po(r)'fek.to/ and revolera /re.bo'le.ra/ (written as rebolera in English): /,re.bə'le.rə/. Although on some occasions effort is devoted to maintaining the full sound or timbre of Spanish vowels, the double transcription offered for the first syllable (non-stressed) in tequila by Merriam-Webster is a good example of the stronger tendency to locate the undefined phoneme $/ \partial /$ in non-stressed syllables following the distribution pattern of the recipient language. This example shows that perception performs differently in production: the phonemes are recognized, as they are found in the recipient language (it would certainly be different if the origin phonemes were totally absent in the recipient language), but adaptation is preferred in utterances.

The vowel phoneme /o/ shows a similar behaviour to / $/$ when integrated in English. Both cover the mid zone, but /o/ is back. In the word-final position, a diphthong is found when the word is integrated in the English lexicon, following the rule stated for the final /e/. Examples of this shift of /o/ into / ov/ or /ov/ (depending on the variety of English) are burrito, caló, cursillo, Hispano and taco. This phenomenon also appears in the first syllables, non-stressed, of conjunto and coqui. The stressed /o/ can adopt different shapes. The long vowel is found in maquiladora/ma.ki.la'do.ra/, which is /,mæ.ki.lə'do:.rə/ in English, but it does not occur in the stressed /o/ of adobo and bandonion, where the diphthong is preferred. The two unstressed /o/ of these last words are also the /ou/ element. Having more variation in the front area, English choices for /o/ are more regular, and this is the reason for having /'gon.zov/(UK) and /'ga:n.zov/(US) in gonzo (/'gon.so/ or /'gon. $\theta \mathrm{o} /$ ), although the final diphthong can be simplified in American varieties, according to the data available in Forvo.

\subsection{Open Vowel /a/}

Finally, the central open phoneme /a/ tends to be / $/$ in unstressed positions, especially in the word-final position: fajita, manoletina, telenovela, turista. The 
stressed $/ \mathrm{a} /$ is usually $/ \mathfrak{x} /$ or $/ \mathrm{a}: /$, sometimes depending on the variety of English: salsa /'sal.sa/is /'sæl.sə/(UK) and /'sa:l.sa/(US), and taco/'ta.ko/is /'tæk.əv/(UK) and /'ta:.kov/(US). The identification between / $\mathfrak{x} /$ and /a/ is common in the opposite direction, from English into Spanish, as stated by Yip: "in languages with a five-vowel system, $[\mathfrak{x}]$ is usually mapped to [a], not [e] (e.g. Fijian, Spanish, Kisukuma), although orthography probably plays a considerable role here" (2006: 958-959). However, the English vowel system is richer in the number of units, so more adaptations can be discovered, and this is the reason why the first /a/ in fajita or Latina differs. In Latina, this first vowel is / $\mathfrak{x} /$ in the UK and US according to the Cambridge Dictionary, but /o/ for Merriam-Webster. When the first syllable is unstressed, it is more probable for the timbre to be preserved, e.g. margarita /mar.ga'ri.ta/: /,ma:.gəa'i..tə/ (UK) and /.ma:(I). gə'xi..to/ (US), suggesting that variation is not always unconditioned even in phonemes having more potential options. Only two words in the corpus show a different timbre of vowels, due to similar words in the recipient language: supremo /su'pre.mo/ is /su:'pxi..mov/ (UK) and /su:'pxi..mov/ (US), and trifecta /tri'fek.ta/ is /trai'fek.to/. In these cases, analogy (related to supreme and the prefix tri-) is responsible for the choices. But, in general, imitation prevails in the adaptation of Spanish vowels into English, under some occurrence conditions (mainly depending on stress), as stated above.

\section{Consonants}

To present consonant phonemes, the different series of units will be followed, as traditionally considered by their manner of articulation. The Spanish system consists of the following phonemes, according to the Real Academia Española

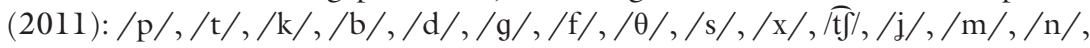
$/ \mathrm{n} /, / \mathrm{l} /, / \mathrm{K} /, / \mathrm{r} /, / \mathrm{r} /$. In most Hispano-American dialects, $/ \mathrm{s} /$ and $/ \theta /$ are absent, and $/ \mathrm{s} /$ is found instead; and $/ \mathrm{h} /$ occupies the place of $/ \mathrm{x} /$. Indeed, $/ K /$ is scarcely used and has disappeared from most territories. The English consonant phonemes listed by Carr (2012) are the following: $/ \mathrm{p} /, / \mathrm{t} /, / \mathrm{k} /, / \mathrm{b} /, / \mathrm{d} /$, $/ \mathrm{g} /, / \mathrm{t} /, / \mathrm{d} 3 /, / \theta /, / \mathrm{d} /, / \mathrm{f} /, / \mathrm{v} /, / \mathrm{s} /, / \mathrm{z} /, / \mathrm{h} /, / \mathrm{s} /, / \mathrm{s} /, / \mathrm{w} /, / \mathrm{l} /, / \mathrm{I} /$, $/ \mathrm{j} /, / \mathrm{m} /, / \mathrm{n} /, / \mathrm{y} /$.

\subsection{Stops and Oral Voiced Series}

The Spanish voiceless stops /p, t, k/ are found in English, although there are several phonetic differences between the two systems. For instance, English voiceless stops ${ }^{10}$ have aspirated variants, in contexts such as word-initial stressed, and stressed, non-word-initial syllables (Umeda and Coker 1974: 3, in the case of 
$/ \mathrm{t} /)$. These variants do not affect the matching process, and / p, t, $\mathrm{k} /$ are maintained in phonological terms in examples such as taco and perfecta. In Spanish, the existence of the $/ \mathrm{p}, \mathrm{t}, \mathrm{k} /$ series in implosive position is subject to discussion, as it is considered that it is neutralized ${ }^{11}$ with the voiced series $/ \mathrm{b}, \mathrm{d}, \mathrm{g} /$. Then, the realization drifts between the variants of the phonemes of each pair: $/ b-p /, / d-t /$, $/ \mathrm{g}-\mathrm{k} /$, voiced approximants being common articulations, although the sound varies according to the immediately following sound. This is the reason why exacta is found in English as / $\mathrm{Ig}$ 'zxk.tə/, following the initial pattern of words such as exhausted in the voiced stop, and also including an implosive voiceless stop and a change in the initial expected vowel.

The Spanish phonemes known as oral voiced, /b, d, g/, are also found in English, although their phonetic characteristics differ in the two languages. In Spanish, they can be stops or approximants, whereas in English they are phonologically stops, and more alveolar than dental in the case of $/ \mathrm{d} /$. In poblano, gonzo and desaparecido, the Spanish $/ \mathrm{b} /, / \mathrm{g} /, / \mathrm{d} /$ matches the English phonemes $/ \mathrm{b} /,^{12} / \mathrm{g} /, / \mathrm{d} /$. Nevertheless, a clarification must be made regarding /d/. In Spanish, the plosive [d] and approximant $\left[\partial_{\tau}\right]$ are variants of $/ d /,{ }^{13}$ but in English the alveolar stop $/ d /$ and fricative dental /ð/ are different phonemes. In adobo and maquiladora, two transcriptions are found in Merriam-Webster for /d/ (articulated as [ð] in Spanish): /d/ and /ð/. Pronouncing [d] (/d/) relates more to orthography, whereas /ð/ is closer to the sound of the Spanish word. This double option shows the different means for adaptation (written and oral), although it seems that /d/ is slightly preferred because there are other words where the Spanish [ð] is assigned to the English /d/. Further investigation of words outside this corpus is required for checking if the /ð/ matching is somehow related to the stressed syllable, which is more audible. In the two examples of double pronunciation, the [ $\left.\partial_{\tau}\right]$ sound belongs to the stressed syllable, while [ð] in the non-stressed syllable of desaparecido and Fidelista is not taken as /ð/ but /d/. The word picadillo (having the English /d/) is the only exception to this hypothetical rule in the corpus. The prevalence of orthography is not as clear in these cases as might be supposed.

\subsection{Fricatives and Affricates}

The fricative series varies among Spanish dialects. In Castilian Spanish there are four units, /f, $\theta, \mathrm{s}, \mathrm{x} /$, whereas many American varieties, as mentioned above, include three: /f, s, h/ (sometimes the choice between $/ \mathrm{h} /$ or $/ \mathrm{x} /$ is not clear). But a difference with English fricatives is shared by Spanish dialects: no voiced units with phonological value appear, and fricatives, mostly voiceless, can be voiced in some contexts, mainly before voiced sounds. Therefore, Spanish fricatives are usually assigned to voiceless English fricatives: $/ \mathrm{f} /$ is $/ \mathrm{f} /$, and $/ \mathrm{h} / \mathrm{h} / \mathrm{x}$ 


\section{Estrella Ramírez Quesada}

Castilian Spanish) is /h/: fajita /fa'hi.ta/becomes /fə'hi:.tə/(UK) and /fə'hi:. to/ or /fa'hi:.tə/(US). The influence of orthography (and similar words such as Hispanic) is responsible for hispano/is'pa.no/ resulting in /hr.'spæ.(.)nov/ in English, adding $/ \mathrm{h} /$ in the conveying process.

The interdental $/ \theta /$ is absent from most American Spanish dialects, so it is not transferred into English. The place that the interdental $/ \theta /$ shares with the alveolar /s / in Castilian Spanish is occupied by the dental /s / in American Spanish, and that makes it common to match the Spanish /s / with the English /s /. In Spanish, it is voiceless when initial in the syllable: salsa (/'sal.sa/) is /'sæl.sə/ (UK) or /'sa:l.sə/ (US). In the intervocalic position it is voiceless in Spanish, and it is generally transferred into English in the same way. However, sometimes English phonological adaptations are based on orthography, and gonzo /'gon.so/ or /'gon. $\theta \mathrm{o} /$ is given the voiced alveolar /z/, typical of the $z$ sign: /'gpn.zəo/(UK), /'ga:n.zou/(US). Sometimes, as stated, the sound in Spanish can be voiced, as /s/ and /s / can be voiced before voiced sounds. In such cases, the English /z/ is preferred, also when the word follows an analogous pattern with native words, e.g. exacta is /Ig'zrk.tə/ (UK and US).

I have stated that no voiced fricative phonemes exist in Spanish, but, as we have just seen, English voiced fricatives can occur as a result of the transfer process, motivated by similar features in the phonemes in the origin language. Thus, the labiodental /v/, absent in Spanish, appears in English when the approximant bilabial $[\beta]$ (allophone of $/ \mathrm{b} /$ ) occurs in Spanish. ${ }^{14}$ In these cases, orthography is considered a determinant factor (ceviche, transcribed in the vowels section, is a good example), as $[\beta]$ shares with $[\mathrm{b}]$ the bilabial feature and is near to $/ \mathrm{v} /$ in being continuant. In similar contexts of $[\beta]$, then, matches are different depending on the orthography: adobo, escabeche, habanero have the English /b/ and huevos rancheros, telenovela, the English /v/. In this corpus, only one word seems to be indifferent to this rule: rebolera (in origin revolera), whose written form has been changed probably to match a plosive pronunciation.

Although they might be phonetically different, Spanish palatals that can be affricate $\left(/ \mathrm{t} \mathrm{S} /\right.$ and $/ \mathrm{j} /$ ) are relocated in similar English phonemes: $/ \mathrm{t} \int /$ and $/ \mathrm{j} /$, respectively. However, when in origin the $/ \mathrm{j} /$ phoneme corresponds to the $l l$ digraph,${ }^{15}$ the lateral $/ 1 /$, orthographically conditioned, tends to be the option; according to Merriam-Webster, sinsemilla and picadillo have both possibilities, and there is only /l/ for tamarillo (yet Forvo shows [1] and [j] for this last word).

\subsection{Nasals and Liquids}

English has more phonemes than Spanish, but Spanish nasals and liquids include some phonemes lacking analogous equivalents in English. Concerning nasals, 
$/ \mathrm{m} /$ and $/ \mathrm{n} /$ are directly transferred; the differences between the two languages are not important, as the nasals are quite comparable in terms of features and distribution. Thus, mano a mano is /.mæn.əv ə 'mæn.əu/(UK) and /.ma:.nov a: 'ma:nov/(US). Nevertheless, the Spanish nasal palatal /n/ has no English equivalence. The imitation of the actual sound is achieved by the sequence $/ \mathrm{nj} /$ : el Niño /el 'ni.no/ is /el 'ni:n.jəo/ (UK) and /el 'ni:n.jou/(US) (note the different syllable structure). As $\tilde{n}$ is not a natural graph for English users, it is sometimes replaced by $n$, with a consequent change of pronunciation: $a \tilde{n} u$ can be found as anu or anyu (and can be articulated with [n] instead of [nj] when it is anu). Phonetically, Spanish nasals in the implosive position take the place of articulation of the following consonant when it is labial, dental, palatal, or velar, being alveolar in other cases. That makes $[\mathrm{y}]$ occur before $/ \mathrm{k}, \mathrm{g}, \mathrm{x} /$. In English, this unit has phonological value, and therefore $/ \mathrm{y} /$ can appear in those contexts: chimichanga.

As far as liquids are concerned, there are three or four units in Spanish: the lateral alveolar $/ \mathrm{l} /$, and the rhotic $/ \mathrm{r} /$ (traditionally known as simple) and $/ \mathrm{r} /$ (multiple). The occurrence of the lateral palatal $/ K /$, as said above, is marginal and therefore is not transferred, being treated phonologically like $/ \mathrm{j} />/ \mathrm{j} /$, or orthographically like $/ 1 /$. The lateral $/ 1 /$ matches the English $/ 1 /$, although contextual allophones may be expected. Similar contexts are shared by the two languages, so the /l/ positions in Latina, población, salsa are not unfamiliar for English native-speakers. On the other hand, the Spanish / $\mathrm{r} /$ and / $\mathrm{r}$ / are not distinguished in English, and they are consequently reduced to the English alveolar approximant $/ \mathrm{I} /$. Two examples of this reduction are burrito /bu'ri.to/: /ba'si.tav/(UK) or /bə'xi:. tov/(US); and jibaro /'hi.ba.ro/ or /'xi.ba.ro/ (written in English as jibaro or gibaro): /'hi:bə,лә兀/(UK) or /'hi:bə,ıou/(US). This equivalence is possibly caused by orthography, and the $r r$ sequence is treated as other digraphs in English, that is, as non-doubled phonemes. Finally, in the implosive position, it can be omitted: margarita /mar.ga'ri.ta/ can be /.ma..gə'i i..tə/ (UK) and /.ma:(I). gə'.ii..tə/ (US), following a common pattern of the written $r$ in English.

\section{Conclusions}

Although the purpose of this paper was mainly descriptive, some considerations can be made about the transferring process of Spanish words into English with regards to the role of phonology. These conclusions also align with some of the points made by the main authors (such as Gil 2007) who have dealt with the difficulties of English learners of Spanish as a foreign language, and the suitability of the concept of phonological deafness in the process. Thus, the field of loanword 


\section{Estrella Ramírez Quesada}

adaptations emerges as a reliable source for studying the phonological systems in confrontation.

The linguistic behaviour of vowels leads us to think that the structure of the recipient language plays a major role in assimilation. The Spanish vowels are assigned to English vowels according to their timbre, mainly in stressed positions, whereas different options - for instance, the choice of $/ \partial /$ - are more probably found in non-stressed contexts. However, the effort to maintain the timbre of Spanish vowels prevails, and therefore there is a tendency in English to have the long vowels /i:/ and / $\mathrm{u}: /$ in stressed syllables, as well as the short vowels /I/ and $/ \mho /$ in non-stressed positions for the Spanish /i/ and / $/$, respectively. As English has more vowels, it is easier to assign a specific phoneme to Spanish units, but the structure of the recipient language is favoured and diphthongs are preferred in word-final positions instead of short vowels different from $/ \partial /$, in accordance with the English pattern. Although some phonemes present more variation than others (the equivalents for the Spanish /a/ are a good example), general trends have been observed. In addition, English being quite variant in the correspondence of vowel signs to vowel phonemes, we have seen that the role of orthography is less important in the subsystem of vowels than in the case of consonants. The loanword adaptation relies mostly on the phonological features and structure of the recipient language, but takes into consideration the similarity in phonetic terms of both languages.

In relation to consonants, no Spanish phonemes are added to the English system. Among the Spanish phonemes with no English equivalent, /n/ is replaced by a sequence of English phonemes $/ \mathrm{nj} /$ or is transformed into $/ \mathrm{n} /$ on an orthography basis, and $/ \mathrm{r} /$ is assimilated to $/ \mathrm{r} /$, the Spanish distinction $/ \mathrm{r}-\mathrm{r} /$ being irrelevant in English. The other phonemes show regular matches with English consonants, although orthography maps some instances of the Spanish /b/ to the English /v/ and some instances of the Spanish /s/- /s / to the English /z/. As stated above, further investigation into words outside this corpus is needed to uncover the circumstances of the Spanish /d/when it is assimilated to /ð/, due to approximant interdental articulation contexts. Generally speaking, it can be concluded that consonants are more influenced by orthography in some situations of choice, possibly because of the closer bond between phoneme and grapheme than in the case of vowels. That principle can be seen in the initial sound of Hispano or the digraph $l l$, treated as the single phoneme $/ 1 /$. Both examples are also conditioned by similar words in the English lexicon. Therefore, the English pattern is determinant also in production.

It might have been assumed that a lack of knowledge of the Spanish language could have led to a stronger dependency on orthography when adopting new 
words for English speakers. But it is confirmed that the imitation of sounds stands out in many cases, showing the importance of the oral reception of words. Neither phonology nor phonetics nor orthography can on their own explain the phenomenon of loanword assimilation, since it is the result of all the factors in combination. Nonetheless, we have seen that phonology gives us the key to understanding the prevalence of some units and the shape they present. This condition shows us that even though the perception of actual elements may not be so far away from those of the target language, the structure of the recipient language imposes some preferences upon the production of foreign-origin words that are phonological to a certain extent. As these preferences mainly depend on occurrence and distribution, they enhance the influence of phonology beyond the distinctive features of phonemes, and allow us to conclude that, when it comes to studying the phonic side of loanwords, phonology must be considered as one of the most illuminating approaches.

\section{Acknowledgements}

This study was carried out as part of Spanish project Los sistemas fonemáticos del español: reexamen teórico y contribución al análisis fonológico del español americano (FFI2017-88367-P) (Ministerio de Economía, Industria y Competitividad). Acknowledgement must also be given to the reviewers for their helpful advice during the editorial process.

\section{Notes}

1. This situation has been widely studied by Calabrese (2009).

2. Cannon's words finally considered were the following: adobo, añu, austral, bandonion, botanica, burrito, caló, ceviche/ seviche, cha-cha, Chicano, chimichanga, chulo, churro, conjunto, coqui, Cruzan, cuatro, cuchifrito, cursillo, desaparecido, El Niño, escabeche, exacta, fajita, Fidelista, flauta, (frijoles) refritos, gonzo, habanero, Hispano, huevos rancheros, inti, jibaro/gibaro, latifundista, Latina, (al) macho, mano a mano, manoletina, maquiladora, margarita, Marielito, Mimbres, nacho, nucleolonema, numero uno, paiche, perfecta, peto, picadillo, población, poblano, rejoneo, revolera, salsa, Sandinista, sinsemilla, superfecta, supremo, taco, tamarillo, telenovela, trifecta and turista.

3. This implies that no archiphonemes are considered, although they are quite common among Spanish functionalists.

4. See Akamatsu (2020) for one of the most recent contributions on the establishment of the English consonantal system.

5. Some analyses, such as Martínez Celdrán (1989), add one or two semivowels 


\section{Estrella Ramírez Quesada}

(see Perea Siller 2020), not affecting the purpose of this paper.

6. Hammond (1999) judges eleven phonemes as basic, and avoids considering /2/.The final sound of happy, movie and coffee (known as happy-words) can be /i:/-like or /I/like (Carr 2012), and can be seen as neutralization, being short as /I/ and close as /i:/ (see Collins and Mees 2013: 104).

7. For example, /ea/ is absent in General American, and some Received Pronunciation speakers pronounce [ $\varepsilon:]$. In fact, $/ æ /, / \varepsilon /$ and $/$ eə/ are all realized as $[\varepsilon]$ before the $/ \mathrm{I} /$ phoneme in General American. See Carr (2012).

8. The Forvo database shows the possibility of eliminating the final diphthong, but the long stressed vowel remains.

9. NavarroTomás (1932: §43) stated that final vowels, when unstressed and produced in a deeper tone, tend to be relaxed and, consequently, have their timbre less clear. $\mathrm{He}$ also mentioned that the loss of definition of Spanish relaxed vowels is not that of the English /o/. Let us remember that in ordinary speech, the timbre is maintained, unlike in English where/ə/ occurs in all speech situations.
10. For some authors (e. g. Collins and Mees 2013), the term stop refers to plosives such as $/ \mathrm{p}, \mathrm{t}, \mathrm{k} /$ and affricates. In this paper, in accordance with Carr (2012) and others, I use stops for traditionally soconsidered English phonemes /p, t, k, b, d, g/.

11. Alarcos Llorach (1965) was the first author who considered neutralizations in the Spanish phonological system, and later phonologists have done the same though not necessarily in accordance with Alarcos's units.

12. The coalescence of $/ \mathrm{b} /$ and $/ \mathrm{v} /$ is mentioned below ( $\$ 5.2)$.

13. [d] occurs in the initial and after nasals and /l/, whereas [ $\mathrm{\partial}$ ] occurs in the other contexts. See Quilis (1999) for a commonly accepted description of Spanish allophones.

14. Occlusive [b] occurs after a pause or nasals. Otherwise, mainly intervocalic, $[\beta]$ is found (Quilis 1999).

15. This digraph used to stand for the lateral palatal $/ K /$, nowadays lost in most Spanish dialects. Its articulations have merged with those of $/ \mathrm{j} /$ in a process of dephonologization, and only /j/ exists.

\section{Works Cited}

AdELL, Eric. 2013. "A Descriptive Account of Spanish Loanword Phonology in Kaqchikel." Kansas Working Papers in Linguistics 34. DOI: 10.17161/KWPL.1808.12862

Akamatsu, Tsutomu. 2020. “Commutation Test in Action: Establishing the English Consonantal Phonematic System". Moenia 25: $345-438$.

Alarcos Llorach, Emilio. (1950) 1965. Fonología española. Madrid: Gredos.

Algeo, John. 1996. "Spanish Loanwords in English by 1900". In Rodríguez González, Félix (ed.): 13-40.

ARnold, Claus. 2015. Spanish Loanwords in American English. Seminar Paper, Johannes
Gutenberg University Mainz. Munich: GRIN Publishing.

Boersma, Paul and Silke Hamann. 2009. "Loanword Adaptation as First-Language Phonological Perception". In Calabrese, Andrea and W. Leo Wetzels (eds.): 11-53.

Calabrese, Andrea. 2009. "Perception, Production and Acoustic Inputs in Loanword Phonology". In Calabrese, Andrea and W. Leo Wetzels (eds.): 59-113. DOI: 10.1075/ cilt.307.03cal

Calabrese, Andrea and W. Leo Wetzels. 2009. "Loan Phonology. Issues and Controversies". In Calabrese, Andrea and W. Leo Wetzels (eds.): 1-10. DOI: 10.1075/cilt.307.01cal 


\section{Phonological Remarks on Spanish Loanwords in English}

Calabrese, Andrea and W. Leo Wetzels (eds.). 2009. Loan Phonology. Amsterdam: John Benjamins Publishing Company. DOI: 10.1075/ cilt.307

CAnNon, Garland. 1996. "Recent Borrowings from Spanish into English". In Rodríguez González, Félix (ed.): 41-60.

CARR, Philip. (1999) 2012. English Phonetics and Phonology: An Introduction. Hoboken: Wiley-Blackwell.

Coluins, Beverly S. and Inger M. Mees. 2013. Practical Phonetics and Phonology: A Resource Book for Students. New York: Routledge.

Forvo. 2021. Forvo. The Pronunciation Dictionary. <https://forvo.com/>. Accessed April 29, 2021.

GIL, Juana. 2007. Fonética para profesores de español: de la teoría a la práctica. Madrid: Arco/Libros.

Hammond, Michael. 1999. The Phonology of English: A Prosodic Optimality-Theoretic Approach. Oxford: Oxford U.P.

Jensen, John T. 2003. English Phonology. Amsterdam, Philadelphia: John Benjamins.

KAnG, Yoonjung. 2010. "Tutorial Overview: Suprasegmental Adaptation in Loanwords". Lingua 120: 2295-2310. DOI: 10.1016/j. lingua.2010.02.015

Kubozono, Haruo. 2006. "Where Does Loanword Prosody Come from? A Case Study of Japanese Loanword Accent". Lingua 116: 1140-1170. DOI: 10.1016/j.lingua.2005.06.010

Martínez Celdrán, Eugenio. 1989. Fonología general $y$ española: fonología funcional. Barcelona:Teide.

Merriam-Webster. 2020. Merriam-Webster Dictionary. <https://www.merriam-webster. com/>. Accessed May 7, 2020.

Navarro Tomás, Tomás. (1918) 1932. Manual de pronunciación española. Madrid: Junta para Ampliación de Estudios.

Peperkamp, Sharon. 2006. "A Psycholinguistic Theory of Loanword Adaptations". In Ettlinger, Marc, Nicholas Fleisher and Mischa ParkDoob (eds.) Proceedings of the Thirtieth
Annual Meeting of the Berkeley Linguistics Society. February 13-16, 2004. Berkeley: Berkeley Linguistics Society: 341-352. DOI: 10.3765/bls.v30i1.919

Peperkamp, Sharon and Emmanuel Dupoux. 2003. "Reinterpreting Loanword Adaptations: The Role of Perception". In Solé, Maria-Josep, Daniel Recasens and Joaquín Romero (eds.) Proceedings of the $15^{\text {th }}$ International Congress of Phonetic Sciences. Barcelona: Universitat Autònoma de Barcelona: 367-370.

Perea Siller, Francisco Javier. 2020. “Tres problemas de fonología en torno a las paravocales". Moenia 25: 439-463.

Quilis, Antonio. (1993) 1999. Tratado de fonología y fonética españolas. Madrid: Gredos.

Ramírez Quesada, Estrella. 2020. “Acerca de la fonología en los procesos de transferencia lingüística". In Santos Rovira, José María (ed.) Raíces y horizontes del español. Perspectivas dialectales, históricas y sociolingüísticas. Lugo: Axac: 227-240.

Real Academia Española and Asociación de Academias de la Lengua Española. 2011. Nueva gramática de la lengua española. Fonética y fonología. Madrid: Espasa.

Rodríguez González, Félix (ed.). 1996. Spanish Loanwords in the English Language. A Tendency towards Hegemony Reversal. Berlin: Mouton de Gruyter. DOI: 10.1515/9783110890617

Rose, Yvan and Katherin Demuth. 2006. "Vowel Epenthesis in Loanword Adaptation: Representational and Phonetic Considerations". Lingua 116: 1112-1139. DOI: 10.1016/j.lingua.2005.06.011

SAYAHI, Lotfi. 2005. "Phonological Adaptation of Spanish Loanwords in Northern Moroccan Arabic". University of Pennsylvania Working Papers in Linguistics 11(1): 253-263.

Schultz, Julia. 2018. The Influence of Spanish on the English Language since 1801. A Lexical Investigation. Newcastle upon Tyne: Cambridge Scholars Publishing.

Serjeantson, Mary S. 1936. A History of Foreign Words in English. New York: Dutton and Company. 


\section{Estrella Ramírez Quesada}

Trubetzkoy, Nikolai S. (1939) 1969. Principles of Phonology. Trans. C.A.M. Baltaxe. Berkeley and Los Angeles: University of California Press.

UmedA, Noriko and Cecil H. Coker. 1974. "Allophonic Variation in American English". Journal of Phonetics 2: 1-5. DOI: 10.1016/ S0095-4470(19)31174-X

University of Cambridge. 2020. Cambridge Dictionary. <https://dictionary.cambridge.org/>. Accessed May 7, 2020.

Vendelin, Inga and Sharon Peperkamp. 2006.

“The Influence of Orthography on Loanword
Adaptations". Lingua 116: 996-1007. DOI: 10.1016/j.lingua.2005.07.005

WINFORD, Don. 2010. "Contact and Borrowing". In Hickey, Raymond (ed.) The Handbook of Language Contact. Chichester:Wiley-Blackwell: 170-179. DOI: 10.1002/9781444318159.ch8

YIP, Moira. 2006. “The Symbiosis between Perception and Grammar in Loanword Phonology". Lingua 116: 950-975. DOI: 10.1016/j. lingua.2005.05.007 